$$
\begin{array}{cccc}
\text { S sciendo } & \text { International Conference KNOWLEDGE-BASED ORGANIZATION } \\
\text { Vol. XXV } & \text { No } 1 & 2019
\end{array}
$$

\title{
DEVELOPMENT AND IMPROVEMENT OF LOGISTICS IN THE BULGARIAN ARMED FORCES: NEW TRENDS AND PERSPECTIVES
}

\author{
Miroslav Stefanov DIMITROV \\ "G. S. Rakovski" National Defence College, Sofia, Bulgaria \\ dimitrovm@abv.bg
}

\begin{abstract}
The paper reveals the opportunities for the development and improvement of logistics in the Bulgarian Armed Forces in the context of NATO transformation. In the context of the Readiness Action Plan (RAP) at the Warsaw Summit in 2016, package capabilities were adopted to define the framework for Bulgaria's commitments to provide logistic support to NATO forces. Using multinational logistics approaches is a key factor in the development of logistic capabilities. The paper discusses focusing on the organization of Host Nation Support in NATO operations and exercises, the use of new technologies and information systems, as well as innovation and integrated logistics support.
\end{abstract}

Keywords: Logistics, Host Nation Support, Information Systems and Technologies.

\section{Introduction}

In recent years, we have witnessed many changes, both internationally and nationally. They are marked by a continuing migratory flow, multiple terrorist incidents, and political changes at international and national levels.

Based on the comprehensive strategic assessment of the international security environment and the resulting threats in the region, the Alliance has developed and adopted a Graduated Response Plans (GRP) for Bulgaria and Romania, one aspect of which is the host nation's readiness and participation to assure the reception and deployment of the NATO Forces.

Bulgarian Armed Forces (AF) must be ready to defend the country's independence and territorial integrity. The readiness of the Bulgarian $\mathrm{AF}$ to conduct joint operations for an adequate response to resolving different crises is our top priority. This requires maintaining the achievements and development of new capabilities, as well as transforming the command and control system.

Our top priority is the readiness of the Bulgarian AF to conduct joint operations for an adequate response to resolving different crises. The development of the techniques used in conducting hybrid wars requires the development of new capabilities in intelligence, cyber protection, radio-electronics, Special Forces, logistics, and transformationof the command and control system.

2. Development and improvement of logistics

One of the systems to be developed in accordance with the changed security environment is the logistics system of the Bulgarian AF. The logistics system should assist, provide and participate in maintaining and developing the necessary defense capabilities, meeting national criteria, indicators and requirements contributing to 
national and collective security and defense, within the limits of the budget capabilities.

The development of effective logistical capabilities means ensuring and meeting the NATO requirements set out in the "Capability Objectives 2017" package, and as a result, the efforts to meet these goals are directed at maintaining, developing and acquiring new capabilities of the declared logistic units. These units also provide logistic support for the deployment of Enhansed NATO Response Forces (eNRF) to the national territory. It is of the utmost importance that they must be provided for collective defense purposes without limitations in their capabilities [1].

Priority in the development of the logistic system is to build capabilities to Host Nation Support of the eNRF involved in operations and exercises across the country. According to the Host Nation Support Doctrine (NP-4.5) 2013, Host Nation Support (HNS) is "Civilian and Military Assistance provided in peacetime, crises or wartime by the Joint Tasks Forse and organizations which are located, operate or pass through its territory" [7].

The military assistance is of the competence and capabilities of the Bulgarian AF and consists of:

- organizing the national participation in the process of negotiating the maintenance by the host nation; providing logistics with available material resources;

- organization of: reception, accommodation and eating; transportation; technical maintenance and repair of armaments, equipment and other means;

- provision of co-location of facilities and facilities of the military infrastructure (military airports, ports, military and warehouse areas, preparation polygons, etc).

Host nation support activities are specified by separate military/technical agreements with the Sending countries involved in the operation and/or the exercises. The residence of forces on the territory of the Republic of Bulgaria is regulated by the Law on the passage through and residence on the territory of the country of allied and foreign armed forces.

For effective planning of support by the host country of the Enhanced NATO Response Forces, the Allied Command Operations has proposed to the Alliance countries, starting in 2016, to develop their own National Capability Mapping National Host Nation Support Capability Planning Catalogs (HNS CAPCAT) under new requirements and in a format specified by SHAPE and the NATO Agency for Communications and Information (NCIA). The Bulgarian Host Nation Support Capability Planning Catalog (BGR HNS CAPCAT) has been developed in this respect. This is an electronic MS Excel format with reference information documents and publications (national, NATO and EU) relating to the maintenance of the Republic of Bulgaria as host country of Allied Forces, which will facilitate the timely organization and implementation of procedures and coordination of maintenance activities at national level. This information will be integrated into the NATO Logistics Information System (LOGFAS) [6].

Another important process related to host nation support is Reception, Staging and Onward Movement (RSOM) and downloading (Disengagement, Rearward Movement, Staging and Dispatch $D \& R M S D)$ to the Enhansed NATO Response Forces. These processes are carried out in close interaction with the NATO Force Integration Units (BGR NFIU) located in our country. A critical phase is the deployment of the arriving forces, which includes the implementation of activities for the reception, unloading, movement and transportation of personnel, armament, equipment and material resources from the places of arrival to their final destination.

RSOM Bulgaria's activities are in line with the SOR and the Host Nation Support signed Technical Agreement (TA). Support is provided through military and civilian capabilities, and is coordinated by the 
RSOM National Commander, the NATO Force Integration Units (BGR NFIU), and the Joint Logistics Support Group (JLSG).

In order to provide logistic support to the NATO Forces in the RSOM / D \& RMSD process, the Bulgarian Armed Forces have assigned formations (groups, modules) for each specific case. Needs that cannot be provided with military capabilities are provided with civilian capabilities, for which purpose the Ministry of Defense initiates the necessary contracts.

During the period 2017 - 2019 several large scale exercises with international participation took place on the territory of the Republic of Bulgaria, such as Trident Jaguar, Noble Jump, Saber Guardian and others. These exercises posed great challenges to logistic structures at all levels because they had to organize, coordinate, and implement all civilian and military peacetime assistance to Allied forces and organizations.

In order to organize the interaction and allocation of responsibilities, working meetings of the interdepartmental working group under the HNS were held. The contact persons from the ministries and institutions with a HNS relationship were identified to be ready to provide the necessary information and actions upon requests from Allied forces. A procedure for interacting and exchanging information on requesting and providing support from ministries and agencies that is being tested during the exercises has been established.

A number of issues and lessons have emerged in the process of analyzing and evaluating the conduct of the exercises. To improve the whole complex of civil and military assistance activities it is necessary to work on the following main directions:

- Improvement of the legislative framework to enable the full implementation of the Alliance for Logistic Support;

- Optimization of the command and management system in the interests of HNS activities and integrate it into the Alliance's collective system;
- Refinement of the preliminary planning and standardization of customs and border procedures, in cooperation with the relevant state authorities;

- Involvement of civilian capabilities (national businesses or international companies) in providing support to NATO forces;

- Changing the regulatory framework to make greater use capabilities of the NATO Support and Procurement Agency;

- Finding a legal-normative solution for the provision of the contracts for securing the Armed Forces of the Republic of Bulgaria for use by allied forces in our territory.

The availability of an adequate and effective system for HNS by the Republic of Bulgaria is an important prerequisite for the timely deployment of Allied forces and resources in the interests of collective security. The further development of the Republic of Bulgaria's HNS system will demonstrate the allied commitment and proper prioritization of the implementation of collective defense mechanisms in the interests of the country's security.

The dynamic nature of the security environment requires military formations to be capable of effective and efficient logistic planning in order to ensure that they can fully complete their tasks in a timely manner. This implies the implementation of modern information technologies, integral part of which is the Information System "Logistics of the Bulgarian Army" [4]. The system was designed as a pilot project funded by the United States under the FMF program, which was completed in 2014. As a result, specialized software was developed, a database maintenance and training system for users of the system was equipped, and the infrastructure for access to the system was established in 30 military units.

The Information System "Logistics of the Bulgarian Army" is an automated information system for monitoring, management and control of the logistic and 
financial processes carried out in the Ministry of Defense and the Bulgarian Armed Forces, which aims to create a unified working environment for all logistic authorities. The system is based on the stateof-the-art software in this area, i.e. "Oracle E-Business Suite". Similar information systems have long been used in all NATO armies, as well as in Austria and Sweden.

The integration of the "Logistics of the Bulgarian Army" Information System in all Bulgarian military formations results in: eliminating the flow of paper documents; significant reduction of corruption risk, because it eliminates any possibility of manipulating the information about the real resources of the material resources; directly binds the planning and implementation processes as it is able to track how far the acquisition process has progressed and how the acquired material resources are used; it provides real-time information about the defficiencies in material resources.

A project under the title of "Support, Implementation and Development of the Information System Logistics of the Bulgarian Army" has been developed for the future enhancement of this system and it is is included in the Ministry of Defense's Portfolio of Projects and Project Priorities. According to this project, this Information System will be integrated in all military formations of the Bulgarian AF by 2021.

Another perspective for increasing the efficiency of the logistic system of the Bulgarian AF is improvement of the obtaining of real-time information about the movement and transportation of units and during operations by making use of the tracking system for obtaining location and real-time vehicle status information [3].

The advantages of using such tracking system by logistics personnel can be summarized as follows:

- Better orientation is achieved and a precise location of the individual means of transport, as well as the means of evacuation and repair is possible;
- Timely information on the status of the means of transport (state of the technical systems, mileage, availability of fuel and ammunition);

- Better opportunities for operational and efficient management of supply and repairs.

The tracking system for the means of transport can be used both in stationary conditions and in a mobile command post for use in both combat and non-combat operations. The implementation of a system for tracking which improves the characteristics of the maintenance subsystems as a whole should be combined with a system for marking and control of the materiel [5].This system is intended to provide the transport system with full and timely information on operations for movement, deployment and maintenance using the same military procedures and rules in peacetime and wartime. It is appropriate if this system is integrated with cargo systems in order to provide information and documentation for both inbound and outbound transport. In addition, it should include a wide range of capabilities for automating transport/receipt, deployment, maintenance and withdrawal processes, site traffic data, transport documentation, and timely information to the appropriate command.

The main functions of the system for marking and control of the materiel are as follows:

-Maintaining a database of the equipment and personnel of the subdivisions, providing deployment operations and traffic control and traffic management units;

-Providing the possibility of automated organization of single and organizational data sheets for deployment in air, sea, rail, land stations and for planning the loading of containers;

- Informing the sender of information about its reliability;

- Accepting data from peripheral devices and recording them on data base. 
The system of marking and control of material resources in the Bulgarian $\mathrm{AF}$ would result in increase of the efficiency of the logistic system by helping to automate the processes of planning, organizing, coordinating and controlling the military deployment of goods and cargo, the maintenance activities, the day-to-day operations of the transport and movement authorities. This is considered to have a positive effect on the entire transport system as a component of logistics security since it provides troops with information to monitor incoming transport and improves the management of cargo and passenger transport both in peacetime and during war.

For the Bulgarian AF, the use of integrated logistics is not only current, but perhaps also the only option in today's realities. This approach is due to the impossibility of providing large stockpiles of spare parts and equipment for the maintenance of armament and equipment. For this, the use of integrated logistic support is necessary because of the optimal use and reasonable use of limited financial resources in the state [2]. Integrated logistics with its complexity of provision can contribute to the possibility of complex weapon systems and equipment being in constant readiness to use, without interruptions in their maintenance and repair. Experience from the operation of newly acquired armament and equipment by the Bulgarian AF shows that due to financial constraints, a cumbersome legislative procedure (or for other reasons), these new systems are acquired without specific commitments for their subsequent maintenance, with a limited set of spare parts, insufficient means of maintenance (part of the checks and especially the calibration of the control equipment are carried out abroad). This factor, in combination with steadily decreasing financial resources and complicated and time-consuming procurement and repair procedures, leads to a sharp reduction in the percentage of non-life equipment after the warranty period, and even to stopping flights of certain types of airplanes and helicopters in the Air Force.

In order to make use of integrated logistic support for armament and equipment in the Bulgarian AF, the following should be implemented:

- Full and continuous coverage of the armament and technology procurement processes at all stages of the product life cycle;

- Centralization of the process management for integrated logistics;

- Functional integration of the processes realized within the framework of the integrated logistic system;

- Orientation towards leading technologies and modern information systems for insurance;

- Opportunity to adapt the integrated logistic processes to the requirements of the specific applicants;

- Cost optimization to ensure the functioning of the integrated logistic system. Analysis of the logistic system has shown that logistic systems should be developed at the strategic, operational and tactical levels in order to fulfill logistic tasks and to preserve the capabilities of the logistic units, with the implementation of logistic structures to be tailored to the specifics of the type of armed force and the capabilities they have to possess to provide troops and forces in fulfilling their assigned tasks.

The established logistic system is subject to continuous assessment and improvement in order to be in a position to provide the necessary logistic capabilities in a timely manner to fulfill mission tasks such as Defense, Support for International Peace and Security and Contribution to National Security in Peacetime. In order to fulfill these tasks and to improve the logistics processes and operations in the operations, the logistic system of the Bulgarian AF can undergo the following main directions for the development in the following years:

- Improving the structures for logistic support of the three levels of command and control; 
- Ensuring adequate support by the host nation in conducting operations and exercises of the eNRF on the territory of the country;

- Completing the declared logistic units with RSOM responsibilities, personnel, and equipment according to their job schedules in accordance with the requirements of NATO standardization documents; conducting training and certification;

- Efficient use of the available material resources to ensure the preparation of the military formations by the Bulgarian $\mathrm{AF}$ and the structures under the direct subordination of the Minister of Defense to maintain and acquire the capabilities for carrying out the missions of the Armed Forces;

- Improving the management of logistics by introducing the information system "Logistics of the Bulgarian Army";

- Improving the system of personnel training in logistic structures.

The transformation of the logistics system should contribute to establishing logistics in the Bulgarian AF, capable of providing compatible military formations that contribute to the realization of the national interests of the country.

The development of the ongoing processes and the course of transformation in NATO member states shows the trend of reducing military budgets and the size of the armed forces. However, the force of the Alliance's agenda is to meet an increasing number of new and increasing tasks related to the movement and transportation of personnel and material resources, the provision of adequate medical care for staff and the management of corresponding flows of information. This puts the Bulgarian military logistics in the forefront of work for implementing a quality logistic support in line with the new requirements for resource economy. This requires the application of new logistic approaches and the use of innovation to solve emerging logistic needs and to achieve success in operations.

\section{Conclusions}

The development of logistics in the Bulgarian AF in the coming years should be focused on improving the capabilities for self-support of military units, combined with the use of the capabilities of multinational logistics, with emphasis on host nation support. Another important task is the wider use and application of new technologies, information systems and innovation by logistic personnel. This necessitates the improvement of the logistic structures at all levels and the optimization of their activities.

\section{References}

[1] Dimitrov Miroslav, Irinkov Vladimir, State and trends in the development of the logistic system of the Bulgarian armed forces, Zeszyty Naukowe Obronność -2018-3, p 35-43

[2] Димитров М. и колектив, Военна логистика-втора част, Основи на многонационалната логистика, София. Издателство на Военна академия, 2017.

[3] Димитров М., Иринков В, Аспекти на развитието на военната логистика в прочеса на планиране и изграждане на системата за колективна отбрана на НАТО, София. Издателство на Военна академия, 2019.

[4] Димитров М., Влияние на инициативата на НАТО „Интелегентна отбрана” върху развитието на военната логистика, Логистиката възможности и предизвикателства, Издателски комплекс УНСС, 2015, стр. 43-53.

[5] Димитров М., Димитров Л., Стефанов И., Основи на многонационалната логистика, София. Издателство на Военна академия, 2010.

[6] Ефтимов Е., Димитров М., Аспекти на осигуряването на адекватна поддръжка от Република България като страна домакин в операции и учения на НАТО и ЕС, Военна академия, Годишник факултет „Командно-щабен”, 2018, стр. 25-34.

[7] НП-4.5-Доктрина за поддръжка от страната домакин, Военно издателство,София, 2013. 